\title{
A IMPLEMENTAÇÃO DO BANCO DE PERFIS CRIMINAIS PELA LEI 12.654/2012 E O LIMITE DA DIVERSIDADE GENÉTICA
}

\author{
IMPLEMENTING THE BANK CRIMINAL PROFILES BY LAW \\ 12.654/2012 AND THE LIMIT OF THE GENETIC DIVERSITY \\ Thais Aline Mazetto Corazza \\ Gisele Mendes de Carvalho \\ Centro Universitário Cesumar - Unicesumar - MARINGÁ- Paraná - Brasil
}

\begin{abstract}
Resumo: a finalidade do presente artigo é analisar a diversidade genética, pela sua importância atual em decorrência dos avanços tecnológicos da bioética e biotecnologia. Para tanto, faz-se um estudo do conceito e alguma considerações, com o fim de estabelecer a aproximação imprescindível à posterior análise crítica de tais institutos. É sabido que os indivíduos de uma mesma espécie não são geneticamente idênticos entre si, possuindo uma combinação única de genes que formam suas características físicas e psíquicas. Embora os genes tragam alguns materiais hereditários, cada pessoa tem genes diferentes, não podendo servir de discriminação genética. Em estudos anteriores César Lombroso comparou criminosos pelas suas características anatômicas, fisiológicas e psicológicas, apontando similaridades para explicar a origem da violência, mas não conseguiu explicar satisfatoriamente as causas da criminalidade. A criação do Banco de Perfis Criminais no Brasil (Lei 12. 654/2012) acaba traçando um perfil criminológico do indivíduo segundo características biológicas das pessoas, surgindo críticas de haveria ressurgido a Escola Lombrosiana. Seria como estabelecer um banco de criminosos natos. Portanto, insurge-se que as pessoas não nascem com "genes criminais", e ainda que se considere que tragam alguma carga de determinismo criminal em si mesmas, isso não pode autorizar a intervenção penal antes que cometam o primeiro crime ou ao menos, antes que o sujeito seja condenado, uma vez que a Lei 12. 654/12 permite o acesso ao banco de dados de identificação de perfil genético enquanto o sujeito ainda está sendo investigado, supondo uma mitigação e afronta ao princípio da presunção de inocência.
\end{abstract}

Palavras-chave: César Lombroso; diversidade genética; limites.

Abstract: the purpose of this article is to analyze the genetic diversity, its importance due to the current technological advances in biotechnology and bioethics. Therefore, it is a study of the concept and some considerations, in order to establish approximation indispensable for further critical analysis of such institutes. It is well known that individuals of the same species are not genetically identical to each other, possessing a unique combination of genes that make up its physical and psychic. Although genes bring some hereditary materials, each 
person has different genes and can not serve as genetic discrimination. In previous studies comparing Cesar Lombroso criminals by its anatomical, physiological and psychological, pointing out similarities to explain the origin of violence, but failed to satisfactorily explain the causes of crime. The creation of the Bank of Criminal Profiles in Brazil (Law 12. 654/2012) just creating a profile of the individual criminological second biological characteristics of individuals, emerging criticism would be resurrected School Lombrosian. Would like to establish a bank born criminals. Therefore, protested that people are not born with "criminal genes", and although it is considered to bring some charge of determinism criminal in themselves, it can not authorize the criminal intervention before they commit the first crime or at least before the individual is doomed, as the Law 12. 654/12 allows access to the database to identify genetic profile while the subject is still being investigated, assuming a mitigation and an affront to the principle of presumption of innocence.

Key-words: César Lombroso; genetic diversity; limits.

\section{Introdução}

A personalidade é tudo aquilo que distingue um indivíduo de outros indivíduos, assim entendendo um conjunto de características psicológicas que determinam a individualidade pessoal e social.

Cada pessoa é dotada de personalidade ao nascer, é um direito inato, inerente à pessoa, como verdadeiras projeções biopsíquicas integrativas da pessoa humana, e acaba com a morte. E é justamente a personalidade, que distingue uma pessoa da outra.

O Brasil é um dos países onde se denota nitidamente a diversidade estampada. Em decorrência da sua formação e colonização, se desenvolveu uma ampla diversidade cultural, biológica, racial, religiosa, entre outros.

No decorrer da história, também a mulher sempre esteve em condição de inferioridade em relação ao homem, este considerado detentor do pátrio poder e por isso superior. Dessa forma, surgiu a diversidade da mulher em relação ao homem.

Ainda, é sabido que a diversidade sexual decorrente da condição de homossexual sempre existiu, mas devido a forte discriminação que havia e a reprimenda que sofriam, ela era escondida, reprimida. Somente há pouco tempo, 
tem-se encarado de maneira mais aberta esse assunto, com decisões em defesa desses grupos.

Ademais, enfermos, portadores de doenças incuráveis, pessoas com regionalismo apurado, sofrem discriminações o tempo todo no Brasil.

Não bastasse, a diversidade genética e o estudo desses genes, que pode e deve contribuir através de seus avanços para uma sociedade mais elevada, tem servido como forma de discriminação, levando a discriminação genética, devido à crença de que algumas condições do indivíduo seriam transferidas hereditariamente pelo gene, como a inclinação à criminalidade.

\section{As formas de diversidade}

Apesar de toda diversidade existente entre os indivíduos, seja ela, genética, cultural, de sexo, religiosa, regional, racial, em decorrência de enfermidade ou doença incurável, entre outras, é sabido que constitucionalmente todos são iguais perante a lei.

A Constituição Federal tratou a igualdade no seu art. $5^{\circ}$, caput e no inciso I. $\mathrm{O}$ caput do art. $5^{\circ}$ menciona a liberdade e a igualdade. Embora sejam conceitos antinômicos, pois se existir liberdade a igualdade desaparecerá, é necessário ligar umbilicalmente os conceitos de igualdade e de liberdade. O sistema democrático não se compatibiliza com a ausência de nenhum desses caracteres, próprios do ser humano. A liberdade não é absoluta, se sujeita a limitações que decorrem da própria necessidade de convivência em harmonia social. Ainda possibilita o desenvolvimento das diferenças entre os homens. $O$ resultado da

liberdade é, primeiramente, a desigualdade econômica, acarretando desigualdade social e desigualdade de oportunidades (SANTOS, 2001, p. 435436).

Apesar da visão antinômica, a liberdade e a igualdade têm forte correlação (BOBBIO, 1996), já que em um Estado que pretende ser democrático não pode haver autêntica igualdade sem liberdade e vice-versa. Essa liberdade com as necessárias restrições deve ser uma igualdade que dê dignidade ao homem. O que fará com que esses dois valores jamais se sobrepõem um ao REVISTA DO DIREITO UNISC, SANTA CRUZ DO SUL №. 44 | p.134-163 | SET-DEZ 2014 
outro é o principio da razoabilidade na aplicação do Direito e é esse equilíbrio harmônico que fará sobreviver os dois conceitos dentro da democracia (SANTOS, 2001, p. 438).

Naturalmente os homens não nascem iguais (PEQUENO, 16 abr. 2014). Uns são mais fortes, outros mais fracos. Possuem conformação física desigual: a cor da pele, o sexo, o peso, as dimensões. A esses elementos somam-se no decorrer da vida, a idade, a saúde. Ainda no seio social, as desigualdades sociais surgem em virtude da aptidão intelectual e da capacidade moral de cada um. Os homens são desiguais e apresentam capacidades intelectuais e físicas diferentes, tipificando a personalidade de cada um, por isso o interesse do Direito em diminuir as desigualdades existentes que excluem a minoria.

A igualdade perante a lei apenas não acaba com essas diferenças existentes. No entanto, a igualdade constitucional não impede que a lei contemple situações que são diferentes sempre que a discriminação consequente não seja arbitrária nem traga privilégio pessoal, o que não significa vulnerar o princípio da igualdade (HERTEL, 2004, p.147; MOLOGNI, 2014; QUARESMA, 2001, P. 1-22). Devem-se tratar os iguais igualmente e os desiguais na medida das suas desigualdades. A "Igualdade não pode ter o mesmo conteúdo de igualitarismo, mas de reconhecimento das diferenças justas e que não tangenciem o privilégio próprio de castas ou de quem se ache superior" (SANTOS, 2001, p. 440).

O respeito às diferenças pessoais, naquilo que a pessoa é e não pode mudar, ou naquilo que ela optou como diretriz de vida está implícito na igualdade tutelada pelo Direito e quaisquer discriminações que coloquem a pessoa em situação de inferioridade afetando sua dignidade deverão ser punidas penal e civilmente.

A igualdade e o tratamento isonômico supõem o direito a ser diferente e somente se realizam com plenitude se for garantido esse direito. Conclusão diversa também não se mostra consentânea com um ordenamento constitucional.

De todos os tipos de diversidade encontrados decorrem discriminação. A diversidade biológica se baseia na diferença do gênero humano, enquanto cor da pele e no sentimento de que uma raça é superior à outra, como exemplo se tem o REVISTA DO DIREITO UNISC, SANTA CRUZ DO SUL No. 44 | p.134-163 | SET-DEZ 2014 
negro (OLIVEIRA, 2004, p. 57-60) e o índio. Esse tipo de diversidade leva à discriminação econômica também, inclusive entre estrangeiros e nativos na obtenção de empregos (SANTOS, 2001, p. 443).

Por este motivo, a Convenção Internacional sobre a Eliminação de Todas as Formas de Discriminação Racial em seu preâmbulo afirma que todos os homens são iguais perante a lei e têm o direito à igual proteção contra qualquer discriminação e contra qualquer incitamento à discriminação. Reafirma o propósito das Nações Unidas de promover o respeito universal aos Direitos Humanos, sem discriminação de raça, sexo, idioma ou religião, enfatizando os princípios da Declaração Universal dos Direitos Humanos, de 1948, em especial a concepção de que todas as pessoas nascem livres e iguais em dignidade e direitos, sem distinção de qualquer espécie e principalmente de raça, cor ou origem nacional. Acrescenta que qualquer doutrina de superioridade baseada em diferenças raciais é cientificamente falsa, moralmente condenável, socialmente injusta e perigosa. Afirma ainda que a discriminação entre os homens por motivos de raça, cor ou origem étnica é um obstáculo a ralações amistosas e pacíficas entre as nações e é capaz de perturbar a paz e a segurança entre povos e a harmonia de pessoas vivendo lado a lado até dentro de um mesmo Estado. $E$ conclui que intimidados por manifestações de discriminação racial em evidência em algumas áreas do mundo e por políticos governamentais baseadas em superioridade racial ou ódio, como as políticas de apartheid, segregação ou separação, resolveram adotar as medidas necessárias para eliminar rapidamente a discriminação racial em todas as suas formas e manifestações (SANTOS, 2001, p. 443-444).

Cretella Jr afirma que:

O indivíduo, interiormente, no fórum internum, pode ter preconceitos, sem que isso prejudique as relações humana de que participa, já que o animus, o interior do homem, o ato intransitivado, é do domínio da ciência estranha ao mundo do Direito. É como o problema da consciência, (estado interno) e do culto (estado externo). Prática do racismo é conduta ou vontade exterior do homem, projetada no mundo exterior, transitivada e, pois, regulada pelo Direito, por limitar o exercício de Direito do indivíduo discriminado. É intolerável, em nossa época, em sociedade aberta e fraterna como a nossa, qualquer tipo de preconceito, 
fundado em cor, raça, religião, convicção política ou filosófica (CRETELLA JÚNIOR, 1989, p. 480).

Percebe-se assim, que quando o preconceito sai do interno, da mente do homem, e se materializa, a discriminação decorrente das características genéticas dá ensejo à demanda de indenização por dano moral.

No que se refere à diversidade religiosa, o Brasil é laico, portanto, não pertence à instituição ou ordem religiosa alguma. $\mathrm{O}$ artigo $5^{\circ}$, inciso $\mathrm{VI}$, da Constituição assegura a inviolabilidade da liberdade de consciência e de crença, sendo assegurado o livre exercício dos cultos religiosos e garantida, na forma da lei, a proteção aos locais de culto e a suas liturgias, denotando assim, o dever do Estado em garantir a liberdade religiosa.

Ainda, a Declaração Universal dos Direitos Humanos, da qual o Brasil é signatário, em seu art. XVIII afirma que "Toda pessoa tem o direito à liberdade de pensamento, consciência e religião". Este direito inclui a liberdade de mudar de religião ou crença e a liberdade de manifestar essa religião ou crença, pelo ensino, pela prática, pelo culto e pela observância, isolada ou coletivamente, em público, portanto a liberdade religiosa é um dos direitos fundamentais da humanidade.

O Brasil é sinônimo de pluralidade, construído por várias raças, culturas, religiões, permite que todos sejam iguais, cada um com suas diferenças e dentro dos limites dela. A intolerância religiosa pátria não gera guerra, como ocorre em países do Meio Oriente, onde "a religião tem sido o refúgio dos fanáticos, que sempre estão prontos a darem a própria vida pela causa religiosa" (SANTOS, 2001 , p. 445), no entanto, o preconceito existe e se manifesta através de humilhação e violência imposta àquele que é considerado "diferente". É do conhecimento de todos a intolerância e discriminação injusta em relação às Testemunhas de Jeová, por não aceitarem transfusão sanguínea (BIZIAK, 2010; TOKARSKI, 2005; PINHEIRO, 2001; MORAES; PIRES, 2005, p. 87-97; BRAÚNA JÚNIOR, 2013; FONSECA, 2011), e aos adventistas, por não fazerem nada no sábado, seguindo ao pé da letra o ensinamento bíblico de que é o sábado o dia de descanso, sendo que ninguém pode ser discriminado pelo só fato de professar uma determinada religião,

REVISTA DO DIREITO UNISC, SANTA CRUZ DO SUL

№. 44 | p.134-163 | SET-DEZ 2014 


\begin{abstract}
Professar uma fé ou exercer uma religião, coloca-se no âmbito interno do ser humano. É a livre manifestação de pensamento, tão útil em Estado democrático e de Direito. A discriminação religiosa será considerada, sempre, um feito arbitrário e odioso. Sem embargo, poderá o Estado exercer o poder de polícia e impedir a propagação de seitas ou religiões que tenham como mote principal o atentado à ordem pública, aos bons costumes e postulem a perversão sexual, ou tolham o exercício da liberdade de seus membros (SANTOS, 2001, p. 446).
\end{abstract}

Percebe-se assim, que a liberdade religiosa é protegida e respeitada, porém, dentro dos seus limites. Não se pode em nome da religião propagar atentados à ordem pública, aos bons costumes e o cunho sexual, muito menos tirar o exercício de liberdade religiosa de seus membros, pois a liberdade de um vai até o limite da liberdade do outro. Ainda, no momento em que alguém é humilhado, discriminado e agredido devido ao seu credo, seus direitos constitucionais e seus direitos humanos são violados.

Percebe-se também que no Brasil há um desrespeito e intolerância muito grande relacionado ao regionalismo (CARDOSO, 2004), onde se descriminam alguns indivíduos pelo seu sotaque ou até mesmo características físicas de uma determinada região. De forma sutil e presente, o Brasil padece de grande mal que é o desrespeito aos nordestinos. A desconfiança e a agressividade com que são tratados, "não sendo raros os epítetos grosseiros e ofensivos que contra eles são lançados como cabeças-chatas, o estereótipo de que o nordestino é sujo, não primando pela limpeza da cidade e que somente serve para elaborar serviços braçais", é fonte permanente de danos à pessoa (SANTOS, 2001, p. 447).

Não bastasse isso, muitas vezes são perseguidos e estimulados a voltarem a sua terra natal, não faltando órgãos da esfera municipal para ajudar e estimular seu retorno. Ainda, ao buscar emprego, se conseguir aprovação, receberá menos do que o seu colega ao lado que exerce idêntica função.

Ainda, quanto à diversidade pela condição de mulher (CRENSHAW, 2002, p. 171-188), é notória a diversidade de sexos imposta. Desde os primórdios o homem sempre esteve em condição de superioridade em relação à mulher (SANTOS, 2001, p. 448). 
Apesar da aparente consciência de que homens e mulheres são iguais em direitos e proteção, não faltou quem considerasse a mulher como objeto e que devesse submissão ao homem (SANTOS, 2001, p. 451). E exatamente nessa sociedade patriarcal e machista que se desenvolveram inúmeros movimentos feministas em busca da emancipação e espaço social da mulher (OLIVEIRA, 1997, p. 39).

No entanto, embora atualmente a mulher tenha conquistado seu lugar na sociedade e possui sua independência, assim como os mesmo direitos formais estabelecidos constitucionalmente, ainda pesa sobre ela o manto da discriminação. Na maioria dos casos, é a mulher sempre a vítima do assédio sexual, a mulher grávida não consegue emprego pela sua condição ou se engravidar no trabalho logo é substituída, na sua admissão tem que demonstrar que não se encontra em estado gravídico, tudo em nome da produção. A mãe solteira também é discriminada no seio social. Percebe-se assim, que a igualdade proclamada pela sociedade é apenas formal, necessitando de sua implementação material para ter eficácia.

Outra forma de diversidade que merece destaque é a decorrente da condição homossexual (RIOS, 2001, p. 154-175). A etimologia da palavra homossexualidade é mista, o prefixo grego homo somado a palavra de origem latina sexualidade que significa inclinação, que pode ser manifesta, aberta, pública, ou oculta para a relação erótica com pessoas do mesmo sexo (SANTOS, 2001, p. 454). Começando pelo aspecto religioso que reprova o homossexualismo por entender ser um pecado que será castigado por Deus, até o aspecto médico, que denota nessa mudança de comportamento sexual problemas de natureza orgânica e genéticos, o perigo atribuído à condição homossexual, tanto para a mulher quanto para o homem, tem levado à marginalização social e à prática constante de discriminações.

A diversidade decorrente de condição social também é estigmatizante e se refere à circunstância dos sujeitos serem diferentes, no entanto, nem sempre a diferença é neutra. Muitas vezes ela se transforma em desigualdade, na medida em que as singularidades dos sujeitos ou dos grupos permitam que REVISTA DO DIREITO UNISC, SANTA CRUZ DO SUL 
alcancem determinados de maneira desigual (ALCUDIA, 2002, p. 14). Assim, essa diversidade se manifesta pelo ser único que cada um é e nasce, como também pela possibilidade ser, ter e participar dos bens sociais, econômicos e culturais.

A condição social de uma pessoa não pode servir como critério para discriminação. No entanto, essa separação é feita acobertada por um manto de qualquer outra atitude que não denota a discriminação. Assim, pessoas mal vestidas não são bem vistas em determinados lugares, e seus cheques, entregues em alguma casa comercial, são recebidos com reservas e muitos cuidados; a riqueza, ou a sua ostentação, abre caminhos nessa sociedade pautada pelo consumismo; a pessoa mais vale pelo que aparenta possuir materialmente; a ambição por um status elevado faz encontrar o tão ambicionado reconhecimento social. Aquele que não se mostra digno dessa condição, medida pelos bens materiais que possui, pode ser maltratado e deixado por último em clara afronta aos princípios da igualdade e, até, da fraternidade cristão (SANTOS, 2001, p. 457).

Existe ainda a diversidade decorrente com a condição de enfermos. As doenças contagiosas não podem afetar a dignidade pessoal do enfermo, nem de sua família, por medo das pessoas de serem contaminadas. Esse não pode ser o pretexto para a discriminação arbitrária.

$\mathrm{Na}$ atualidade, os maus-tratos a que é submetido o homem doente desvaloriza a todos os indivíduos, porém a desvalorização mais se acentua nos seres mais desvalidos, sejam crianças, anciãos e enfermos. O enfermo é uma pessoa. Viver com dignidade esta condição requer o respeito de elementares direitos da personalidade (SANTOS, 2001, p. 459).

Ainda, a maior vítima de discriminação atualmente é o aidético (AYRES, 2006), e nesse contexto se inserem as crianças que herdaram a doença de seus pais (ZUCCHI, 2010, p. 719-734). Assim, empresas fúnebres negam-se a enterrar ou embalsamar os mortos por Aids, os pacientes são expulsos dos lugares, os filhos de enfermos não têm sido recebidos nos colégios e hospitais, e a maioria das clínicas privadas se negam a receber ditos enfermos por temor ao contágio e a perder clientes que pensam que podem ser contagiados. Não se lhes permitem REVISTA DO DIREITO UNISC, SANTA CRUZ DO SUL 
o trabalho em hospitais, colégios, indústrias, etc., são proibidos de ingressar nas Forças Armadas. As companhias de seguro de vida não fazem contrato de seguro com aqueles contagiados pela Aids e a maioria dos institutos de saúde da previdência não incluem entre seus riscos de saúde a infecção por HIV. (SANTOS, 2001, p. 460).

Os doentes, portadores do vírus HIV, têm direito como qualquer outro enfermo, a receber da comunidade a assistência idônea, a compreensão respeitosa e uma plena solidariedade.

Já no que se refere à diversidade decorrente da condição de portador de deficiência, nota-se que em vários momentos a Constituição de 1988 procurou amparar as pessoas que sofrem de alguma deficiência, como se percebe em seus artigos 23, inciso II; 227, $\S 1^{\circ}$, inciso II; $244 ; 203$, incisos IV e V; $227, \S 2^{\circ}$; art. $7^{\circ}$, inciso XXXI e 37, VIII que garantem direitos aos portadores de deficiência. No entanto, denota-se uma proteção constitucional abrangente, não se tolerando nenhuma forma de discriminação arbitrária (DIAS, 2001), porém, não se cuida do deficiente de maneira a possibilitar meios concretos para sua integração na sociedade em que vive.

A arquitetura de prédios e o sistema viário não permitem simples deslocação física. Os ônibus não contêm dispositivos que permita o fácil acesso de deficientes. Nas ruas e logradouros públicos, bem como prédios que abrigam cinemas, teatros ou outros espaços de lazer, quase sempre não possuem rampas e adequação para melhor locomoção do portador de alguma deficiência. É imensa a dificuldade para conseguirem emprego, pelo só fato de serem deficientes e não porque a atividade exigirá aquela função ou sentido que falta ao incapacitado. A própria maneira como são tratados, chamados de deficientes, inválidos, minusválidos, são formas que bem denotam a inferioridade (SANTOS, 2001, p. 462).

É fato que algumas organizações não governamentais, assim como algumas pessoas individualmente procuram mitigar o sofrimento e limitações daquele que sofre de alguma deficiência física (GOMES, 2000). Qualquer tratamento diferenciado dado a essas pessoas e que não respeite sua situação particular de indivíduo é considerada injusta discriminação. Deve se atentar para REVISTA DO DIREITO UNISC, SANTA CRUZ DO SUL 
o fato de algumas vezes essa discriminação vir acobertada pelo exercício regular de um direito, como por exemplo, uma empresa deixar de contratar um cego, porque para desempenhar o trabalho ali existente é imprescindível que todos enxerguem e muito bem (SANTOS, 2001, p. 464).

Por fim, de grande importância na atualidade, devido a época que se vive de avanços tecnológicos e estudos genéticos, tem-se a diversidade genética. Os indivíduos de uma mesma espécie não são geneticamente idênticos entre si. Cada indivíduo possui uma combinação única de genes que fazem com que alguns sejam mais altos e outros mais baixos, alguns possuam os olhos azuis enquanto outros os tenham castanhos, tenham o nariz chato ou pontiagudo. As diferenças genéticas fazem com que a Terra possua uma grande variedade de vida.

O Brasil é um dos países mais ricos em biodiversidade (VIEIRA, 2006, p. 101) e a diversidade genética está dentro dessa biodiversidade, juntamente com a diversidade orgânica e ecológica. A palavra gene surgiu em 1910 fazendo referência a uma unidade abstrata de herança que governa traços específicos de uma determinada espécie e após estudos, surgiu o conceito abstrato de gene como unidade fundamental da herança. Avançaram-se os estudos e descobriu-se o ácido desoxirribonucleico (DNA), o ácido ribonucleico (RNA) e as proteínas e "implícito nesses avanços estava o conceito de gene como informação determinante das características e comportamento dos seres vivos e mecanismos transmissor dessas características através das gerações" (CARVALHO, 2007, p. 29).

Por volta de 1883, Wilhelm Roux defendeu que os cromossomos seriam os responsáveis pelo transporte dos fatores hereditários dentro das células. No início do século $X X$, o inglês $E$. B. Wilson confirmou a existência do cromossomo $X$ como fator determinante do sexo, confirmando os estudos a respeito da herança ligada ao sexo (CARVALHO, 2007, p. 29-30).

A respeito da herança genética tem-se que:

Ao longo da história Genética, restou comprovado que, embora o DNA presente nos cromossomos constitua o mais importante repositório do material genético existente em um organismo, elementos extranucleares

REVISTA DO DIREITO UNISC, SANTA CRUZ DO SUL

№. 44 | p.134-163 | SET-DEZ 2014 


\begin{abstract}
ou citoplasmáticos também contêm parte do material responsável pela transmissão dos caracteres hereditários. A herança extracromossômica, ou não-mendeliana, reside principalmente nas mitocôndrias, organelas que constituem a principal fonte de energia dos organismos eucariontes. É importante registrar, contudo, que esses elementos comportam apenas uma pequena porção do material hereditária das células, e por isso não chegam a representar uma parte importante do genoma dos seres humanos (CARVALHO, 2007, p. 30).
\end{abstract}

Assim, embora os genes tragam materiais hereditários, cada pessoa tem uma combinação genética diferente, até mesmos os gêmeos idênticos ou univitelinos, possibilitando a diversidade genética. $\mathrm{O}$ uso que a sociedade pode fazer da informação genética abre muitas portas, as quais em sua maioria são positivas, como o é a possibilidade de identificação, prevenção e cura de enfermidades hereditárias, porém outras são de caráter negativo, com a possível discriminação pelo seu uso, a chamada discriminação genética (HAMMERSCHMIDT, 2007, p. 173).

Portanto, o uso da informação genética e sua investigação não podem servir como forma de discriminação, seja nas relações de trabalho, nas relações civis, no caso de contratar seguro de vida ou no âmbito penal.

\title{
3 A dignidade da pessoa humana e a isonomia como limite da diversidade
}

A diversidade e sua tolerância têm limites claros, vez que não existe tolerância onde está presente a desigualdade, fruto de relações de dominação entre indivíduos ou grupos sociais.

A menor unidade concebível é o indivíduo. Um único judeu vivendo entre os evangélicos é uma unidade cultural minoritária. Embora, portanto, a Declaração Universal sobre Diversidade Cultural tenha a finalidade de proteger a diversidade cultural de unidades culturais maiores do que a de um indivíduo "essa proteção será em última análise deficiente, a menos que se estenda ao indivíduo; e este é o sujeito dos direitos humanos. Portanto, para ser consistente, o direito à diversidade cultural tem que ser pensado como um direito humano: o direito de cada indivíduo humano à diversidade" (CICERO, 2007).

Respeitar as diversidades não pode significar aceitar as desigualdades sociais. Por isso tolerância não significa apenas uma aceitação passiva entre os 
diferentes, mas uma ação positiva solidária na superação das desigualdades sociais. A tolerância tem limites claros que começam com a não aceitação da intolerância e das relações de exploração entre classes/grupos sociais

Nesse sentido é clara a lição de Clodoaldo Meneguello Cardoso ao afirmar que,

\begin{abstract}
A tolerância enquanto reconhecimento da diversidade cultural contrapõe-se à hegemonia de qualquer cultura que domina e marginaliza as demais. Portanto, a tolerância tem limites claros. Não se pode tolerar a intolerância nas relações de exploração entre povos, classes ou grupos sociais. Sem limites a tolerância seria sua própria negação (CARDOSO, 2003, p. 20).
\end{abstract}

O tratamento isonômico e a igualdade pressupõe o direito a ser diferente. Deve-se usar sempre o princípio da isonomia e a dignidade da pessoa humana diante do direito de diversidade. Na expressão certeira de Luís Roberto Barroso, a dignidade da pessoa humana assume dimensão transcendental e normativa, e a Constituição passa a ser não somente "o documento maior do direito público, mas o centro de todo o sistema jurídico, irradiando seus valores e conferindo-lhe unidade" (BARROSO, 2010, p. 60).

Ainda, diante de um caso concreto, não se pode conferir à lei uma interpretação diferente da constitucionalmente aceita. Ao apreciar as demandas que envolvam princípios fundamentais deve-se atentar para o papel do juiz que, segundo John Rawls, não pode invocar as próprias noções pessoais de moralidade, nem os ideais e virtudes da moralidade em geral, nem visões religiosas ou filosóficas. Estes devem ser considerados irrelevantes (SANDEL, 2011, p. 310).

No mesmo sentido, sobre direito e moral, Chaïm Perelman afirma que "pode haver boas razões para que as regras morais não sejam inteiramente conformes às regras jurídicas, pois estas são sujeitas a condições de segurança, a presunções e a técnicas de prova, com as quais o juízo moral não se embaraça muito" (PERELMAN, 2005, p. 305).

O Estado existe para auxiliar os indivíduos na realização dos seus projetos pessoais de vida, com seu livre e pleno desenvolvimento da personalidade. A cobertura da dignidade engloba prestações de cunho material e a dimensão existencial do princípio da dignidade, pois uma vida digna não se resume à REVISTA DO DIREITO UNISC, SANTA CRUZ DO SUL 
integridade física e à suficiência financeira. Uma vida digna requer a possibilidade de concretização de metas e projetos e quando o Estado não possibilita isso se fala em dano existencial. Assim, veda-se ao Estado obstar que os indivíduos busquem a própria felicidade, a não ser em caso de violação ao direito de outrem, esse é o limite. Por tais motivos, a sociedade e sua diversidade devem ser analisadas sobre os valores atuais, pois se fosse possível analisar como foram os últimos dois mil anos, haveria casamento arranjado aos doze anos de idade, com uma pessoa desconhecida; a esposa ainda seria propriedade do marido, podendo dispor dela; uma pessoa poderia ser presa por ter se casado com outra de raça diferente; e seria impossível o divórcio (CHAVES, 2011, p. 305). Com as transformações sociais, evoluem também suas instituições e juntamente a análise jurídica dos fenômenos.

$O$ tratamento isonômico supõe $\mathrm{o}$ direito a ser diferente, $\mathrm{O}$ direito a autoafirmação e a um projeto de vida independente de tradições e ortodoxias. Para se realizar plenamente o direito a igualdade, deve-se garantir o direito a diferença. Nesse sentido Douglas Willian afirma que "a tradição existe por algum motivo e não deve ser mudada pelo voto de um pequeno grupo, mas pela consulta ao grande público ou através de seus representantes, eleitos para isso" ${ }^{1}$. Nessa mesma linha, tem-se a resposta negativa à pergunta de Ronald Dworkin ao questionar "será que uma 'maioria moral' pode limitar a liberdade de cidadãos individuais sem uma justificativa melhor do que a de desaprovar suas escolhas pessoais?" (DWORKIN, 2005, p.645).

Sabe-se que o povo é o legitimador do poder, pois segundo o art. $1^{\circ}$, parágrafo único, da Constituição Federal tem se que "Todo o poder emana do povo, que o exerce por meio de representantes eleitos ou diretamente", porém, como figura central da democracia, cumpre indagar que é o povo? (MÜLLER, 2011, p. 53-56). Sobre o assunto Bonavides complementa que isso é ocorre porque o regime representativo - que possui como fonte de poder o "povo" - não é necessariamente um regime democrático. Vale dizer, pois, que pode ocorrer "representação" sem democracia, e democracia sem "representação", como

1 DOUGLAS, William. Dois Surdos - Os religiosos e o movimento gay. Revista Jurídica Consulex, São Paulo: Consulex, 2011 (345): p. 46-47, data 01.06.2011. 
aconteceu a partir da constituição francesa de 1791, cujos eleitos governavam "de costas voltadas para o corpo político, para o eleitorado, para aquela coletividade democrática, contemporaneamente conhecida pelo nome de povo" (BONAVIDES, 1968).

Nesse sentido, povo é um conceito plurívoco, não se identificando com a maioria da população votante. Na democracia o acesso ao poder é estabelecido pela maioria, mas isso não significa que o exercício do poder tem como destinatário essa maioria legitimadora do acesso ao poder. O Estado só é verdadeiramente democrático se além de sua forma, o seu conteúdo também for. O problema da legitimação democrática tem dimensões mais elásticas e por isso, nem sempre se resolve pela regra majoritária que justifica apenas o acesso ao poder. Esta é a razão de as ações do Estado prestigiar também os não votantes, como, por exemplo, as crianças, os presos, os eleitores facultativos e, de resto, as minorias vencidas pelo voto. O problema da legitimação democrática deve ser analisado pela universalização das prescrições do Estado, o qual será legitimado quando considerado o povo não apenas como a fonte do poder, mas também como o destinatário de suas ações, ou como a "totalidade dos atingidos pela norma", ou seja, bem diferente da maioria votante. O povo não é apenas - de forma indireta - a fonte ativa da instituição de normas por meio de eleições bem como - de forma direta - por meio de referendos legislativos; ele é o destinatário das prescrições, em conexão com deveres, direitos e funções de proteção. E ele justifica esse ordenamento jurídico num sentido mais amplo como ordenamento democrático, à medida que o aceita globalmente, não se revoltando contra o mesmo. Nesse sentido ampliado, vale o argumento também para os não eleitores, e igualmente para os eleitores vencidos pelo voto (tocante ao direito eleitoral fundamentado no princípio da maioria) ou para aqueles cujo voto foi vitimado por uma cláusula limitadora (MÜLLER, 2011, p. 53-56).

Essa visão distorcida de que democracia seja o governo da maioria também foi apontada por Ronald Dworkin, ao criticar processos políticos que, embora formalmente democráticos, relegavam ao ocaso minorias sociais destituídas de expressão político-eleitoral, como foi o caso dos negros e homossexuais, em determinado momento da história dos Estados Unidos: 


\begin{abstract}
A hipótese do processo político justo também é duvidosa quando o grupo que perde foi vítima histórica de um preconceito ou estereótipo que torna provável que seus interesses sejam desprezados pelos eleitores. (...) Em primeiro lugar, o grupo pode ser tão marginalizado financeira, social e politicamente, que lhes faltem meios para chamar a atenção dos políticos e dos outros eleitores para seus interesses e, assim, não exercer o poder nas urnas, ou em alianças ou barganhas com outros grupos, que se esperaria que o número de componentes do grupo fosse capaz de produzir. Em segundo lugar, pode ser vítima de vieses, preconceitos, ódios ou estereótipos tão graves que a maioria queira reprimi-lo ou puni-lo por tal motivo, mesmo quando as punições não sirvam a nenhum outro interesse, mais respeitável ou legítimo, de outros grupos (DWORKIN, 2005, p. 654-656).
\end{abstract}

De fato, a soberania popular não é absoluta, quanto ao exercício do poder e aos destinatários das ações públicas e a regra da maioria não pode se afastar do fato de que "o bem comum, hoje, tem um nome: são os direitos humanos, cujo fundamento é, justamente, a igualdade absoluta de todos os homens, em sua comum condição de pessoas" (MÜLLER, 2011, p. 22).

Em outras palavras, a maioria, através dos seus representantes eleitos, não pode sob o manto da democracia, decretar perda de direitos civis da minoria pela qual possa ter aversão. Em regra, é o Poder Judiciário - e não o Legislativo - que exerce um papel contra majoritário e protetivo exatamente por não ter compromisso com as maiorias votantes, mas apenas com a lei e com a Constituição, sempre em vista a proteção dos direitos humanos fundamentais, tanto das minorias, quanto das maiorias. Por isso, ao contrário do que pensam os críticos, a democracia se fortalece quando se reafirma como forma de governo de todos e não apenas das maiorias.

O direito de diversidade decorre dos direitos de minorias, dos direitos fundamentais básicos em nossa Constituição, do direito fundamental à liberdade de livre desenvolvimento da personalidade do indivíduo, da garantia de não discriminação dessa liberdade de opção (art. $5^{\circ}, \mathrm{XLI}, \mathrm{CF}$ ), dentre outros, os quais exigem um dever de proteção. O que se busca enfatizar é que, ao se fazer simplesmente uma equiparação irrestrita na aplicação do princípio da igualdade com a finalidade de pôr fim às minorias, pode-se acabar equiparando também situações que vão revelar diversidades (STJ, Relator: Ministro LUIS FELIPE SALOMÃO, Data de Julgamento: 25/10/2011, T4 - QUARTA TURMA). 
Entre as finalidades do Estado também está a de tutelar valores morais, preservar costumes, permitir o convívio de diversidades e variados referenciais, gerados a partir da coexistência entre individualidades e padrões plúrimos de convivência, não cabendo mais ao Estado apenas para impor ao jurisdicionado parâmetros estereotipados. Agregar e fundar a fraternidade, a união das pessoas, protagonizar a tolerância e não criar normas que as deixem à margem do ordenamento jurídico, em função de credo, da classe social, da raça, da orientação sexual, porque o Estado não existe apenas para satisfazer ou legitimar os interesses das maiorias, e mesmo das classes dominantes, cumprindo-lhe velar também pelos direitos das minorias, sob pena de omitir-se exatamente no cumprimento de uma das suas principais funções, que é a de propiciar alternativas e sistemas de inclusão, repudiando discriminações que apenas incentivam a marginalização de condutas destes que não mais se contentam em ver apenas tolerado o perfil sócio familiar, almejando e merecendo, sim, se ver admitidos e legitimamente incluídos no cotidiano (STJ, Relator: Ministro LUIS FELIPE SALOMÃO, Data de Julgamento: 25/10/2011, T4 QUARTA TURMA).

Toda intervenção direta do Estado na vida privada das pessoas somente se justifica atualmente se tiver por finalidade realizar a proteção do indivíduo, dos princípios constitucionais da dignidade da pessoa humana e da isonomia, para garantir-lhe direito ou cobrar-lhe obrigações. É necessário ir além da promoção de uma atitude apenas tolerante para com a diferença, o que em si já é, sem dúvida, uma grande tarefa. É preciso ser humano.

\section{A implementação do banco de perfis criminais pela lei $12.654 / 2012$ e o limite da diversidade genética}

Atualmente vivencia-se a quinta dimensão ou geração de direitos, que representam os novos direitos advindos das tecnologias de informação, do ciberespaço e da realidade virtual em geral, começa-se a pensar hodiernamente em medidas alternativas pré-delitivas, algumas já inclusive promulgadas em leis de recente implantação, como forma de prevenção criminal.

REVISTA DO DIREITO UNISC, SANTA CRUZ DO SUL

№. 44 | p.134-163 | SET-DEZ 2014 
Os direitos de quinta dimensão são os novos direitos advindos das tecnologias de informação (internet), do ciberespaço e da realidade virtual em geral. A informática, a eletrônica, os computadores e a rede de Internet se difundiram com rapidez inacreditável, reformatando os negócios, a produção e o trabalho (SCHWENCK, 2001), auxiliando sobremaneira o trabalho inclusive dos juristas e na elucidação de crimes.

A validade dos contratos virtuais e a autenticidade da assinatura digital são assuntos hodiernos, juntamente com o a criminalidade da informática. Canais de informações se tornam eficientes e rápidos. Serviços de informações de toda ordem, com transmissão de dados, notícias, previsões financeiras, de tempo, passam a ser indispensáveis para a produção econômica, para o comportamento privado e até para as atividades dos órgãos dos governos. Todos anseiam por mais e mais informações atualizadas (SCHWENCK, 2001).

A criação de banco de dados de informações aliada ao direito penal começa a auxiliar a elucidação de crimes, assim como a descoberta de códigos genéticos únicos para cada pessoa. A pena de prisão, que não resolve o problema da criminalidade, passa a ser substituída por medidas alternativas, mais favoráveis a prevenção criminal. Surgem atualmente novas medidas alternativas pré-delitivas, como a monitoração eletrônica, o banco de perfis genéticos para fins criminais e a castração química. Uma revolução social e jurídica profunda é enfrentada atualmente pela humanidade, e por isso, se faz necessário rever o sistema legal pátrio.

Por certo, os "novos" direitos materializam exigências permanentes da própria sociedade diante das condições emergentes da vida e das crescentes prioridades determinadas socialmente (WOLKMER, 2013, p. 125).

Esse processo do nascimento de direitos novos referentes ao homem, ainda que favorecido pelos ideais da cultura liberal-burguesa e pela doutrina do jusracionalismo deve-se em grande parte, à estreita conexão com as transformações da sociedade (BOBBIO, 1992, p. 73). Assim, o desenvolvimento e a mudança social estão diretamente vinculados com o nascimento, a ampliação e a universalização dos novos direitos. 
Nesse contexto, de elevada importância o estudo da diversidade genética e implementação do Banco de Perfis Criminais pela Lei 12. 654/2012. Os indivíduos de uma mesma espécie não são geneticamente idênticos entre si. Cada indivíduo possui uma combinação única de genes possibilitando diferentes características físicas, por isso alguns são mais altos e outros mais baixos, alguns possuem os olhos azuis enquanto outros os têm olhos castanhos, uns têm o nariz chato, enquanto outros têm nariz pontiagudo. Essa diferença genética entre as pessoas possibilita que o planeta possua uma grande variedade de vida.

O Brasil é um dos países mais ricos em biodiversidade (VIEIRA, 2006, p. 101) e a diversidade genética está dentro dessa biodiversidade, juntamente com a diversidade orgânica e ecológica. Ao longo da história Genética, restou comprovado que embora os genes tragam materiais hereditários, cada pessoa tem uma combinação genética diferente, até mesmos os gêmeos idênticos ou univitelinos, possibilitando a diversidade genética. $O$ uso que a sociedade pode fazer da informação genética abre muitas portas, as quais em sua maioria são positivas, como o é a possibilidade de identificação, prevenção e cura de enfermidades hereditárias, porém outras são de caráter negativo, com a possível discriminação pelo seu uso, a chamada discriminação genética (HAMMERSCHMIDT, 2007, p. 173).

No direito penal, a fundamentação da pena teve como ponto central de discussão o que justificaria sua imposição. Tradicionalmente fundamenta-se a existência de culpabilidade, que configura elemento essencial do conceito do delito juntamente com a tipicidade e antijuridicidade.

O conceito formal de culpabilidade significa que essa ação pode ser imputada subjetivamente ao autor, pela reprovação que lhe efetua o ordenamento jurídico, por sua ação ilícita, na situação concretamente considerada. O entendimento da culpabilidade do sujeito como fundamento e limite da pena (princípio da culpabilidade) exige o conceito material de culpabilidade, ou seja, qual a razão pela qual se desaprova no indivíduo a realização de uma ação típica e antijurídica. O livre arbítrio foi o pano de fundo dos debates (CASABONA, 1999, p. 108-110). 
O primeiro passo foi dado por Lombroso com sua famosa Teoria do delinquente nato, onde apoiado ao método cientifico empírico, buscou encontrar características anatômicas, fisiológicas e psicológicas em alguns delinquentes, chegando à conclusão que os delinquentes assim caracterizados estava determinado a delinquir, motivo pelo qual não seria cabível nele apreciar uma responsabilidade moral. Essa teoria foi posteriormente desmentida, mas manteve até os dias atuais discussões a partir de outras reflexões. A pena estaria baseada na periculosidade revelada pelo delinquente, no risco que apresentaria de voltar a cometer delitos (CASABONA, 1999, p. 110-111).

Posteriormente, estudos buscaram encontrar bases biológicas na criminalidade e nelas um certo valor preditivo. Seria exaustivo expor cada uma dessas investigações, assim dentre elas pode-se destacar os tipos anatômicoscaracterológicos da personalidade (Biotipologia) de Kretschmer, Sheldon e S. e E. Glueck, a endocrinologia (em relação às alterações hormonais e sua influência na personalidade) e a neurofisiologia, entre outras (CASABONA, 1999, p. 111).

$\mathrm{Na}$ Genética criminal, a comprovação estatística da incidência de doenças mentais e de criminalidade entre pessoas com parentesco consanguíneo incentivou o estudo científico da influência da herança biológica na conduta criminal, centrando-se na comparação de grupos de gêmeos monozigóticos e polizigóticos, estudo da genealogia de famílias delinquentes, filhos adotivos, alterações cromossômicas. Como se vê, alguns destes estudos, já se dirigem a vincular, ainda de forma bastante rudimentar, a criminalidade à hereditariedade (CASABONA, 1999, p. 111).

Entretanto, nenhum desses estudos foi decisivo e relevante no sentido de explicar de maneira satisfatória as causas da criminalidade, e na realidade, poderiam apenas chegar à conclusão que parte da população criminal poderia apresentar algumas alterações biológicas que explicassem estatisticamente a tendência de seus portadores à prática de delitos, mas isso seria uma tendência, sem que essa explicação pudesse ser elevada à categoria de máxima geral (CASABONA, 1999, p. 112).

$\mathrm{O}$ direito de diversidade, assim também entendido o direito à diversidade genética, é decorrência primeira dos direitos de minorias, dos direitos REVISTA DO DIREITO UNISC, SANTA CRUZ DO SUL 
fundamentais básicos da Constituição Federal de 1988, do direito fundamental à liberdade de livre desenvolvimento da personalidade do indivíduo, da direito a não discriminação.

No entanto, ao se aplicar o princípio da igualdade irrestritamente estará criando diversidades também, uma vez que os desiguais devem ser tratados na medida de suas desigualdades, não podendo ser todos tratados de maneira equânime. Ao Estado cumpre várias finalidades, dentre elas, permitir o convívio de diversidades, protagonizando a tolerância e não criar normas que as deixem à margem do ordenamento jurídico.

Qualquer forma de intervenção do estado diretamente na vida privada das pessoas, somente encontra justificativa no cenário atual, se tiver por finalidade realizar a proteção do indivíduo, dos princípios constitucionais da igualdade e principalmente da dignidade da pessoa humana, para garantir-lhe direito ou cobrar-lhe obrigações. Necessário se faz ir além da promoção de uma atitude apenas tolerante para com a diferença.

A implementação do Banco de Perfis Criminais pela Lei 12. 654/2012 veio como tentativa de auxiliar na investigação criminal, assim como na identificação civil do indivíduo. A função dos bancos de dados genéticos nada mais é do que o armazenamento de perfis de DNA colhidos de amostras de material genético humano. Têm por objetivo a investigação criminal e identificação civil. $\mathrm{Na}$ investigação criminal se coleta amostras em locais de crime e é feita a comparação com os perfis de suspeitos, enquanto que na civil as amostras de parentes de pessoas desaparecidas são coletadas e armazenadas a fim de compará-las com amostras recolhidas em cadáveres ou em locais de crime (NAVES, 2010, p. 144). A coleta do perfil genético pode se dar de várias maneiras, como através de raspas de pele, fios de cabelo com raiz, pedaços de unha, sêmen, sangue, saliva, entre outros.

Assim, entende-se por bancos de perfis genéticos aqueles bancos de dados com o fim de armazenar sequências genéticas para posterior cruzamento de informações, podem armazenar amostras de vestígios do local do crime ou ainda amostras doadas pelos suspeitos. 
No entanto, conforme já citado, em estudos anteriores, como os de Lombroso, isso já foi feito, de traçar um perfil segundo características biológicas das pessoas. Não obstante, a grande preocupação que surge é a de respeitar os direitos fundamentais e não dar brechas a estigmatizações, destinando o banco genético aos casos pontuais.

Assim, surgem críticas do retorno ao positivismo lombrosiano:

Em muitos momentos temos a sensação de que Lombroso ainda não morreu. O direito penal continua sendo legislado contra algumas pessoas, sobre as quais recai a suspeita de periculosidade. Cuida-se do chamado Direito penal de autor. O pior é que o projeto aprovado diz que o banco de dados deve ser formado desde o momento em que o sujeito foi "averiguado" (investigado). A presunção de inocência está cada vez mais esquecida, porque vivemos o tempo do Direito penal de Guerra (contra o inimigo) (GOMES, 17 abr. 2014).

O banco de perfis genéticos pode assim, trazer consequências desastrosas, próprias de um Estado Totalitário e não Democrático "Isso é algo delirante, que se constrói, a pretexto, de combate de forma eficaz ao crime, etiquetando os criminosos, já levando a sociedade a chamá-los de criminosos, no contexto lombrosiano, dando tratamento policial a problemas sociais". E complementa,

É o ressurgimento perigoso, no direito brasileiro, da escola de Lombroso, do direito penal do autor. Tal, num Estado Democrático de Direito, deve ser objeto de diversas limitações. Além disso, a pirotecnia sensacionalista encontra nesse banco de dados um forte aliado. Vamos estabelecer um banco de criminosos natos. Isso em pleno século XXI, num Estado Democrático de Direito. A identificação genética, da forma que está, é um retrocesso, a serviço da demagogia criminal (ROMANO, 17 jun. 2013).

Isso porque essa forma de acesso à intimidade genética encontra-se intimamente vinculada a um pensamento que superestima o papel da carga hereditária na configuração não apenas da saúde como também do comportamento humano de modo geral, criando uma espécie de "determinismo genético" que ignora a função decisiva desempenhada pelo ambiente, pela educação e pela própria liberdade do homem na conformação de seu futuro (DARÍO BERGEL, 1998, p. 42).

REVISTA DO DIREITO UNISC, SANTA CRUZ DO SUL

N. 44 | p.134-163 | SET-DEZ 2014 
Essa concepção, porém, carece de fundamento, se considerado que a realização progressiva do conteúdo genético existente já na célula inicial de um organismo está condicionada, em maior ou menor medida, à atuação de fatores ambientais (ABRISQUETA ZARRABE, 1999, p.158; SOUZA, 2001, p.108-129).

Vale destacar que as características e comportamentos humanos são produto de uma interação entre dotação genética (genótipo) e entorno social (fenótipo), sendo tão equivocado dizer que os genes determinam completamente a atuação do homem quanto negar que boa parte do que ele é deriva da herança que lhe foi transmitida por seus ascendentes (ABRISQUETA ZARRABE, 1999, p.158).

Observe-se que não tem sentido a ideia, que na atualidade ganha cada vez mais adeptos, de que a culpabilidade criminal estaria completamente determinada por fatores genéticos, de forma que a reprovabilidade que recai sobre o autor de um fato típico e ilícito não mais teria razão de ser, já que deixaria de existir a ideia de liberdade de atuação conforme o Direito que fundamenta o juízo de censura a ele dirigido. O homem agiria condicionado por seus genes, e não poderia ser declarado culpável de uma conduta cuja realização já se encontra programada pelo código de genético de cada uma de suas células, que ele próprio jamais poderia alterar. Salta à evidência que o absurdo desse ponto de vista é que todos os acusados deveriam ser declarados inimputáveis, aplicando-se-Ihes medidas de segurança em lugar de penas, tal como propunha a Escola Positiva do Direito Penal no século XIX, auge do positivismo e do determinismo biológico como forma de explicação do comportamento humano, capitaneado por Cesare Lombroso. Defender semelhante posicionamento, portanto, é retroceder no tempo e aceitar uma escusa que "representaria um modo muito mais fácil e 'limpo' de explicar nossa conduta em sociedade do que ter que lidar com tantas e imprecisas influências 'sociais' que se encontram no ambiente" (CAVOUKIAN, 1995, p. 59).

Diante da tendência à divulgação desse tipo de informação, que poderia levar ao surgimento de um "cidadão transparente" aos olhos não só do Estado, como também da sociedade em geral, sustenta-se que deveria ser resguardado sempre o direito subjetivo de recusar-se a participar dessa espécie de exame, REVISTA DO DIREITO UNISC, SANTA CRUZ DO SUL 
pois a subordinação de direitos individuais aos interesses coletivos implicaria nesse caso um manifesto desrespeito à autonomia e à liberdade humanas (CAVOUKIAN, 1995, p. 68-69) e principalmente à dignidade da pessoa humana e igualdade, limites do direito à diversidade genética.

Em síntese, o acesso à informação genética de outrem e a admissão de exceções ao direito à intimidade, encontram-se condicionados por um valor que serve como fundamento e limite a todos os direitos fundamentais e principalmente ao direito à diversidade genética: o respeito à dignidade da pessoa humana (art. $1^{\circ}, \mathrm{II}, \mathrm{CF}$ ). Assim, se por um lado é certo que em alguns casos, nos quais se encontra em risco a segurança de terceiras pessoas, o direito à privacidade da informação genética deve ceder, não assumindo contornos absolutos, também é certo que o homem deve ser protegido em seu direito de não ver devassado o seu genótipo e inclusive de ignorar sua constituição quando assim o prefira.

Não há direitos fundamentais ilimitados e seu limite é aportado pelo princípio da dignidade da pessoa humana. O mais importante, portanto, é que esse princípio esteja sempre a assegurar o respeito devido às decisões, intenções e manifestações de consentimento dos indivíduos afetados, impedindo qualquer tentativa de valorar as ações humanas por suas características pessoais, em virtude de raça, sexo, crença ou condição social e excluindo, certamente, o determinismo positivista como força de justificar o comportamento social do homem.

Conclui-se assim que, as pessoas não nascem com "genes criminais" e ainda que tragam alguma carga de determinismo criminal em si mesmas, isso não pode autorizar a intervenção penal ou violação da sua intimidade genética. $O$ limite está no respeito à dignidade da pessoa humana.

\section{Considerações finais}

Em um país com tanta diversidade, que aflorou em virtude de sua formação e colonização, chegando até os dias atuais Brasil, a diversidade se desenvolveu amplamente em todos os sentidos, tanto cultural, biológico, racial, 
religioso, regional, em decorrência da condição sexual, da condição de enfermo, da condição social, dentre outros.

Possuem grande importância e traços atuais a diversidade genética, em decorrência dos avanços tecnológicos da bioética, biotecnologia, etc. É sabido que os indivíduos de uma mesma espécie não são geneticamente idênticos entre si, possuindo uma combinação única de genes que formam suas características físicas e psíquicas, fazendo com que alguns sejam mais altos e outros mais baixos, alguns possuam os olhos azuis enquanto outros os tenham castanhos, tenham o nariz chato ou pontiagudo. É justamente em razão da diversidade genética que o planeta Terra tem uma grande variedade de vida.

Com o descobrimento e o surgimento da palavra gene começaram os estudos dos traços específicos de uma determinada espécie e sua herança genética, descobrindo-se posteriormente o ácido desoxirribonucleico (DNA), o ácido ribonucleico (RNA) e as proteínas, ligando o conceito de gene às informações que determinavam as características e comportamento dos seres vivos, assim como transmitiam essas características através gerações. Ainda o cromossomo faria o transporte dos fatores hereditários dentro das células.

No entanto, descobriu-se também que embora os genes tragam alguns materiais hereditários, cada pessoa tem genes diferentes, não podendo servir de discriminação genética, que pode ocorrer nas relações laborais, civis e penais.

César Lombroso, em seu livro $\mathrm{O}$ Homem Delinqüente, comparou criminosos apontando similaridades para explicar a origem da violência, separando-os biologicamente em três tipos principais de delinqüentes.

Entretanto, seu estudo não foi decisivo e relevante para explicar satisfatoriamente as causas da criminalidade. Chegou-se apenas a conclusão que parte da população criminal poderia apresentar algumas alterações biológicas que explicassem estatisticamente a tendência de seus portadores à prática de delitos, sem que essa explicação pudesse ser elevada à categoria de máxima geral

Hoje em dia, depois de numerosos estudos desenvolvidos nessa área, implantou o Banco de Perfis Criminais no Brasil, com a Lei 12. 654/2012, com o fim de armazenar sequências genéticas para posterior cruzamento de REVISTA DO DIREITO UNISC, SANTA CRUZ DO SUL №. 44 | p.134-163 | SET-DEZ 2014 
informações, podem armazenar amostras de vestígios do local do crime ou ainda amostras doadas pelos suspeitos.

As aplicações de um perfil criminal elaborado a partir de certo crime são inúmeras. Por meio dele, podemos estabelecer se estamos lidando com um criminoso serial, eliminar suspeitos, elaborar técnicas investigativas com base no tipo de ofensor procurado, estabelecer comunicação com o agressor por meios de comunicação, preparar interrogatórios, estabelecer busca de provas e vincular crimes aparentemente únicos, além da diminuição de custos que se daria pela redução do número de suspeitos e do tempo de investigação.

A elaboração de perfis criminais é uma técnica investigativa que infere aspectos psicossociais do criminoso com base em uma análise psicológica, criminalística e forense de seus crimes, orientando, assim, com eficiência a investigação ao diminuir o número de suspeitos, estabelecendo uma estratégia de ação, planejando um método de interrogatório mediante um suspeito e capturando o perpetrador do crime.

Porém, Lombroso já havia traçado um perfil criminológico do indivíduo segundo características biológicas das pessoas, assim como acontece com o Banco de Perfil Criminal, surgindo críticas de haveria ressurgido a Escola Lombrosiana, recaindo a suspeita de periculosidade sob os investigados, mitigando o princípio da presunção da inocência. Até mesmo porque, a lei permite que o banco de dados seja formado desde o momento em que o sujeito foi investigado.

O banco de perfis genéticos acaba por etiquetar os criminosos, no contexto lombrosiano, tratando policialmente problemas que são sociais. Seria como estabelecer um banco de criminosos natos.

O acesso à informação genética de outrem e a admissão de exceções ao direito à intimidade, encontram-se condicionados por um valor que serve como fundamento e limite a todos os direitos fundamentais e principalmente ao direito à diversidade genética: o respeito à dignidade da pessoa humana (art. $1^{\circ}, \mathrm{III}, \mathrm{CF}$ ). O mais importante, portanto, é que esse princípio esteja sempre a assegurar o respeito devido às decisões, intenções e manifestações de consentimento dos indivíduos afetados, impedindo qualquer tentativa de valorar as ações humanas REVISTA DO DIREITO UNISC, SANTA CRUZ DO SUL 
por suas características pessoais, em virtude de raça, sexo, crença ou condição social e excluindo, certamente, o determinismo positivista como força de justificar o comportamento social do homem.

Portanto, insurge-se que as pessoas não nascem com "genes criminais" e ainda que tragam alguma carga de determinismo criminal em si mesmas, isso não pode autorizar a intervenção penal ou violação da sua intimidade genética. $O$ limite está no respeito à dignidade da pessoa humana.

\section{Referências bibliográfica}

ABRISQUETA ZARRABE, José Antonio. Genes y discriminación. Revista de Derecho y Genoma Humano, $n^{\circ} 11,1999$.

ALCUDIA, Rosa. Et al. Atenção à diversidade. Trad. Daisy Vaz de Moraes. Por Alegre: Editora Artmed, 2002.

AYRES, José Ricardo; FRANÇA JR, Ivan; PAIVA, Vera. Crianças e jovens vivendo com HIV/Aids: estigma e discriminação. Revista ComCiência, v. 76, 2006.

BARROSO, Luís Roberto. Curso de direito constitucional contemporâneo. 2 ed. São Paulo: Saraiva, 2010.

BIZIAK, Daniel Dovigo. A Recusa de Transfusão de Sangue por Motivos Religiosos. Revista Eletrônica da Faculdade de Direito de Franca, v. 2, n. 1, 2010.

BOBBIO, Norberto. A Era dos Direitos. Trad. Carlos Nélson Coutinho. 5 reimp. Rio de Janeiro: Campus, 1992.

BOBBIO, Norberto. Igualdade e liberdade. Rio de Janeiro: Ediouro, 1996.

BONAVIDES, Paulo. O regime representativo e a democracia. Revista de Direito Público. RDP 3/99. jan.-mar/1968.

BRAÚNA JÚNIOR, José. Vida e liberdade: a recusa de pacientes Testemunhas de Jeová a tratamento com transfusão sanguínea, à luz dos direitos fundamentais. 2013

CARDOSO, Clodoaldo Meneguello. Tolerância e seus limites: um olhar latinoamericano sobre diversidade e desigualdade. São Paulo: UNESP, 2003.

CARDOSO, Oscar Valente et al. O regionalismo e seus efeitos sobre o princípio da não-discriminação e a cláusula da nação mais favorecida. 2004. 
CARVALHO, Gisele Mendes de. Patrimônio genético \& direito penal. Curitiba: Juruá, 2007.

CASABONA, Carlos María Romeo. Do gene ao direito: sobre as implicações jurídicas do conhecimento e intervenção no genoma humano. São Paulo: IBCCrim, 1999.

CAVOUKIAN, Ann. La confidencialidad en la genética: la necesidad del derecho a la intimidad y el derecho a "no saber". Revista de Derecho y Genoma Humano, n" 2, 1995.

CHAVES, Marianna. Homoafetividade e direito. Curitiba: Juruá, 2011.

CICERO, Antonio. Os limites da diversidade cultural. Folha de São Paulo, 15 dez/2007.

CRENSHAW, Kimberlé. Documento para o encontro de especialistas em aspectos da discriminação racial relativos ao gênero. Estudos feministas, v. 1, $p$. 171-88, 2002.

CRETELLA Jr, José. Comentários à Constituição de 1988. Rio de Janeiro: Forense Universitária, 1989. Tomo I.

DARIOO BERGEL, Salvador. Derechos humanos y genética: los principios fundamentales de la Declaración Universal sobre el Genoma y los Derechos Humanos. Revista de Derecho y Genoma Humano, $n^{\circ}$ 9, 1998, p.42).

DIAS, Luiz Cláudio Portinho. O Panorama atual da pessoa portadora de deficiência física no mercado de trabalho. Revista Jurídica Eletrônica Trimestral, Rio Grande do Sul, n. 3, Março, 2001.

DOUGLAS, William. Dois Surdos - Os religiosos e o movimento gay. Revista Jurídica Consulex, São Paulo: Consulex, p. 46-47, de 01 jun. 2011.

DWORKIN, Ronald. A Virtude soberana: teoria e prática da igualdade. Trad. Jussara Simões. São Paulo: Martins Fontes, 2005, p. 645.

FONSECA, Ana Carolina da Costa et al. Autonomia, pluralismo e a recusa de transfusão de sangue por Testemunhas de Jeová: uma discussão filosófica. Revista Bioética, v. 19, n. 2, 2011.

GOMES, Joaquim B. Barbosa. Instrumentos e métodos de mitigação da desigualdade em direito constitucional e internacional, v. 4, n. 12, 2000. Disponivel em: <http://egov.ufsc.br/portal/sites/default/files/anexos/31989-375071-PB.pdf> Rio de Janeiro. Acesso em: 16 abr. 2014. 
GOMES, Luiz Flávio. Aprovado o banco de perfis genéticos: Lombroso ainda não morreu. Disponivel em: <http://jus.com.br/revista/texto/20090/aprovado-o-bancode-perfis-geneticos-lombroso-ainda-nao-morreu\#ixzz2WUgJDKEW>. Acesso em:17 abr. 2014

HAMMERSCHMIDT, Denise. Intimidade Genética \& direitos da personalidade. Curitiba: Juruá, 2007.

HERTEL, Daniel Roberto. Reflexos do princípio da isonomia no direito processual. Revista do Centro Universitário Vila velha (ES), v. 5, n. 1/2, jan/dez 2004, v. 4, n. 1/2, p. 147, 2003.

MOLOGNI, Celina Kazuko Fujioka et al. As ações afirmativas em favor dos homossexuais: fundamentos jurídicos. UNOPAR Científica Ciências Jurídicas e Empresariais, v. 6, n. 1, 2014.

MORAES, Rodrigo lenacco de; PIRES, Rodrigo Esteves Santos. Transfusão de sangue em pacientes Testemunhas de Jeová: religião, ética e discurso jurídicopenal. Revista Jurídica Unijus, Uberaba, v. 8, p. 87-97, 2005.

MÜLLER, Friedrich. Quem é o povo? A questão fundamental da democracia. Trad. Peter Naumann. 6 ed. São Paulo: Editora Revista dos Tribunais, 2011.

NAVES, Bruno Torquato de Oliveira. Direitos de personalidade e dados genéticos: revisão crítico-discursiva dos direitos de personalidade à luz da "natureza jurídica" dos dados genéticos humanos. Belo Horizonte: Escola Superior Dom Helder Câmara - ESDHC, 2010, p. 144.

OLIVEIRA, Fátima. Ser negro no Brasil: alcances e limites. Estudos Avançados, V. 18, n. 50, p. 57-60, 2004.

OLIVEIRA, Malu. Homem e Mulher - a caminho do século XXI. São Paulo: Editora Ática, 1997.

PEQUENO, Marconi. O fundamento dos direitos humanos. Disponível em: $<$ http://www.dhnet.org.br/dados/cursos/edh/redh/01/02_marconi_pequeno_funda mento_dh.pdf>. Acesso em: 16 de abril. 2014.

PERELMAN, Chaïm. Ética e direito. 2 ed. São Paulo: Martins Fontes, 2005.

PINHEIRO, Douglas Antônio Rocha. Testemunhas de Jeová: uma análise simbólica do conflito motivado pela recusa em se submeter a tratamentos com transfusões sanguíneas. Orientador: Prof. Dr. José Nicolau Heck. Defesa em 2001 , v. 3.

QUARESMA, Regina. Comentários à legislação constitucional aplicável às pessoas portadoras de deficiência. Teperino, MP, organizador. Comentários à 
legislação federal aplicável às pessoas portadoras de deficiência. Rio de Janeiro: Forense, 2001, p. 1-22.

SANDEL, Michael J. Justiça - o que é fazer a coisa certa. Trad. Heloisa Matias e Maria Alice Máximo. Rio de Janeiro: Civilização Brasileira, 2011.

RIOS, Roger Raupp; PIOVESAN, Flávia. A discriminação por gênero e por orientação sexual. Seminário Internacional: as minorias e o direito. Série Cadernos do CEJ, n. 24, p. 154-175, 2001.

ROMANO, Rogério Tadeu. Identificação criminal pelo DNA: uma experiência lombrosiana.

Disponível

em:

$<$ http://www.jfrn.gov.br/jfrn/institucional/biblioteca/doutrina/Doutrina305-

identificacao-criminal-pelo-dna.pdf > Acesso em: 17 abr. 2014.

SANTOS, Antonio Jeová. Dano moral indenizável. 3 ed. São Paulo: Editora Método, 2001.

SCHWENCK, Terezinha. Os novos direitos. Jus Navigandi, Teresina, ano, v. 7 , 2001. Disponível em: <http://jus.com.br/artigos/2566/os-novos-direitos>. Acesso em: 06 set. 2013.

SOUZA, Paulo Vinícius Sporleder de. A criminalidade genética. São Paulo: RT, 2001.

TOKARSKI, Mariane Cristine. Liberdade e vida: a recusa à transfusão de sangue à luz dos direitos fundamentais. Jus Navigandi, Teresina, ano 10, $n$. 891, 11 dez. 2005. Disponível em: <http://jus.com.br/artigos/7711>. Acesso em: 16 abr. 2014.

VIEIRA, Tereza Rodrigues. Bioética: temas atuais e seus aspectos jurídicos. Brasília: Consulex, 2006.

WOLKMER, Antonio Carlos. Introdução aos fundamentos de uma teoria geral dos "novos" direitos. Revista Jurídica, v. 2, n. 31, p. 121-148, 2013.

ZUCCHI, Eliana Miura et al. Estigma e discriminação vividos na escola por crianças e jovens órfãos por Aids. Educação e Pesquisa, v. 36, n. 3, p. 719-734, 2010. 